\title{
KERAGAMAN MORFO-FISIOLOGI BENIH SUREN (Toona sinensis) DARI BERBAGAI TEMPAT TUMBUH DI SUMATERA DAN JAWA
}

Seed morpho-physiological variation of suren (Toona sinensis)

from various growth sites in Sumatra and Java

\author{
Dharmawati F. Djam'an dan Dede J. Sudrajat \\ Balai Penelitian dan Pengembangan Teknologi Perbenihan Tanaman Hutan \\ Jl. Pakuan Ciheulet PO BOX 105 Bogor, Jawa Barat, Indonesia \\ email: upiefd@gmail.com
}

Tanggal diterima: 23 Desember 2016, Tanggal direvisi: 2 Februari 2017, Disetujui terbit: 30 November 2017

\begin{abstract}
Suren (Toona sinensis) is a potential multipurpose species that is more cultivated at upland community forests, especially in Java and Sumatra islands. This research was aimed to assess the variation of fruit and seed morphophysiological characters and to investigate the contribution of geoclimate and genetic factors on the fruit and seed morpho-physiological characters of suren. Seeds were collected from seven populations in West Sumatera, Jambi and West Java on March - May 2015. Morphological parameters measured were size and weight of fruits and seeds, while the physiological parameters measured were seed germination and storability. Analysis of variance revealed significant morpho-physiological differences among populations for all the morphophysiological parameters studied. Cimalaka population provided the better seed quality compared to seed quality from the other populations, mainly for seed physiological parameters. Most of the parameters was not correlated with geo-climate factors, except for number of empty seed that negatively correlated with mean annual temperature and seed wing width negatively correlated with altitude. Genotypic variance and genotypic coefficient of variance for all fruit and seed parameters were found to be higher than corresponding environment variance and environment coefficient of variance, indicating that the genotype explained most of the variance for these parameters. In particular, high heritability values coupled with high genetic gain were found for germination capacity and germination speed. Principal component analysis of various parameters of fruit and seed revealed that most of the geographically distant populations are genetically close.
\end{abstract}

Keywords: genotype, heritability, morpho-physiology, phenotype

\begin{abstract}
ABSTRAK
Suren (Toona sinensis) merupakan jenis potensial multiguna yang banyak dibudidayakan di hutan rakyat dataran tinggi, khususnya di Pulau Jawa dan Sumatera. Tujuan penelitian ini adalah untuk mengkaji keragaman morfofisiologi buah dan benih dan untuk mengetahui besarnya kontribusi faktor geoklimat dan genetik terhadap karakteristik morfo-fisiologi buah dan benih suren. Benih dikumpulkan dari tujuh populasi di Sumatera Barat, Jambi, dan Jawa Barat pada bulan Maret-Mei 2015. Parameter morfologi yang diukur adalah ukuran dan berat buah dan benih, sedangkan parameter fisiologi yang diukur adalah perkecambahan dan daya simpan benih. Analisis ragam menunjukkan perbedaan morfo-fisiologi buah dan benih yang nyata antar populasi untuk semua parameter yang diuji. Populasi Cimalaka memberikan kualitas benih yang lebih baik dibandingkan dengan kualitas benih dari populasi lainnya, terutama untuk parameter fisiologi benih. Sebagian besar parameter tidak berkorelasi dengan faktor-faktor geoklimat, kecuali untuk jumlah benih hampa yang berkorelai negatif dengan suhu rata-rata tahunan tempat tumbuh, dan lebar sayap benih yang berkorelasi dengan ketinggian tempat tumbuh. Ragam genotipe dan koefisien ragam genotipe untuk semua parameter buah dan benih ditemukan lebih tinggi daripada ragam lingkungan dan koefisien ragam lingkungan yang memberi indikasi bahwa genotipe mampu menerangkan sebagian besar keragaman untuk parameter-parameter tersebut. Nilai heritabilitas yang berpasangan dengan kemajuan genetik yang tinggi ditemukan pada parameter daya dan kecepatan berkecambah. Analisis komponen utama terhadap parameter buah dan benih menunjukkan bahwa populasi-populasi yang berdekatan secara geografik mempunyai kedekatan secara genetik.
\end{abstract}

Kata kunci: genotipe, heritabilitas, morfo-fisiologi, fenotipe

\section{PENDAHULUAN}

Suren (Toona sinensis (A. Juss.) M. Roem, sinonim Cedrela sinensis) merupakan jenis pohon yang memiliki banyak manfaat. Kayunya bernilai ekonomi tinggi sebagai bahan venir, kayu lapis, kontruksi, furnitur, kerajian, sedangkan bagian tanaman lainnya seperti daun, 
biji dapat digunakan untuk bahan obat-obatan dan kosmetik (Chen, 2012; Wu et al., 2014) dan insektisida tradisional (Asmaliyah \& Ismail, 2013; Darwiati, 2009). Jenis ini merupakan jenis asli India dan Nepal yang diintroduksi ke arah timur melewati China, Burma, Thailand, Malaysia hingga ke Jawa (Edmonds \& Staniforth, 1998). Pertama kali suren ditanam di India dan Sri lanka sebagai tanaman naungan dan kemudian menjadi tanaman penghasil kayu penting termasuk di Indonesia dan Philipina. Sampai saat ini informasi keragaman suren yang tumbuh di Indonesia masih terbatas, termasuk informasi morfo-fisiologi benihnya. Penyebaran suren pertama kali ke Indonesia diduga berasal dari materi genetik yang sempit namun sebaran tumbuh yang beragam dan adaptasi yang cukup lama kemungkinan mampu menciptakan ras lahan yang mempunyai karakteristik berbeda, termasuk keragaman morfo-fisiologi buah dan benihnya. Informasi keragaman morfo-fisiologi benih ini dapat dijadikan acuan awal adanya keragaman genetik sebagai informasi dasar untuk kegiatan pemuliaan suren.

Keberadaan suatu jenis tumbuhan dalam suatu tegakan hutan tropis sangat dipengaruhi oleh faktor-faktor lingkungan yang sangat kompleks yang salah satunya adalah kondisi geoklimat tapak. Berbagai penelitian menunjukkan bahwa faktor iklim (curah hujan, suhu dan kelembapan), ketinggian tempat merupakan faktor yang berpengaruh nyata terhadap kehadiran dan pertumbuhan suatu jenis tumbuhan (Whitmore, 1998). Studi perbedaan parameter buah dan benih antar populasi telah banyak dilakukan pada jenis-jenis tanaman hutan seperti Trigonobalanus doichangensis di China (Zheng, Sun, Zhou, \& Coombs, 2009), Pinus wallichiana di India (Rawat \& Bakshi, 2011), Jatropa curcas di India (Gairola, Sharma, \& Dwivedi, 2011). Abies nordmanniana di Western Black Sea Region, Turki (Sevik, Yahyaoglu, \& Turna, 2012)Cedrus deodara di Jammu dan Kashmir (Mughal \& Thapliyal, 2012), Senna siamea di Thailand (Takuathung, Pipatwattanakul, \& Bhumibhamon, 2012), dan
Anthocephalus cadamba (Sudrajat, 2016). Penelitian-penelitian tersebut menunjukkan adanya keragaman morfo-fisiologi buah dan benih antar populasi sebagai parameter awal untuk mengidentifikasi keragaman genetik dan karakterisasi sifat-sifat morfologi yang membedakan populasi satu dengan yang lainnya. Variasi morfologi dan fisiologi benih selain dipengaruhi oleh faktor lingkungan (geoklimat) juga dikontrol oleh faktor genetik (Pathak, Debroy, \& Rai, 1984) dimana pada jenis dengan keragaman genetik yang rendah kemungkinan sedikit sekali perbedaan parameter morfo-fisiologi antar kelompok benih dari populasi berbeda atau kemungkinan perbedaan yang terjadi lebih disebabkan oleh pengaruh lingkungan (Ghildiyal, Sharma, \& Gairola, 2009; Sudrajat, 2016). Tujuan penelitian ini adalah untuk mengkaji keragaman morfo-fisiologi buah dan benih dan untuk mengetahui besarnya kontribusi faktor geoklimat dan genetik terhadap karakteristik morfo-fisiologi buah dan benih suren. Informasi keragaman morfo-fisiologi ini diharapkan menjadi acuan awal bagi kegiatan konservasi genetik dan pemuliaan.

\section{BAHAN DAN METODE}

\section{A. Bahan penelitian}

Pengumpulan buah dilakukan di 7 populasi suren di Sumatera Barat, Jambi dan Jawa Barat (Tabel 1) pada bulan Maret - Mei 2015. Jumlah pohon induk setiap lokasi bervariasi dari 10 pohon induk. Untuk mendapatkan variasi genetik yang optimum jarak antar pohon induk dipertahankan pada kisaran 50 $\mathrm{m}$. Buah yang dikumpulkan dari setiap lokasi selanjutnya diproses di Laboratorium Benih, Balai Penelitian dan Pengembangan Teknologi Perbenihan Tanaman Hutan (BPPTPTH) Bogor. Benih diekstrak dari buah secara manual per pohon induk dengan dengan cara dijemur di bawah sinar matahari selama 2 hari hingga buahnya merekah, kemudian dimasukkan ke dalam karung dan dikoyakkan sehingga benihnya keluar dan selanjutnya benih ditampi 
untuk memisahkannya dengan kotoran. Benih dikeringanginkan selama 2 hari di bawah sinar matahari hingga kadar air berkisar 10-12\%, kemudian dikemas dalam wadah plastik kedap udara dan diberi identitas sesuai dengan lokasi pengunduhannya. Data lapangan yang dikumpulkan adalah letak geografis, ketinggian tempat (menggunakan GPS), curah hujan, dan suhu rata-rata tahunan (data dari BMKG setempat).

\section{B. Pengukuran karakteristik buah dan benih}

Pengukuran karakteristik buah dan benih dilakukan di Laboratorium Pengujian Benih, BPPTPTH Bogor. Setiap lokasi diwakili oleh 150 buah yang diambil secara acak sebanyak 15 buah dari setiap pohon induk. Karakteristik buah yang diukur adalah panjang buah, diameter buah, berat buah, jumlah benih isi per buah, jumlah benih hampa per buah. Diameter buah diukur dengan kaliper digital terhadap diameter terbesar dan diameter terkecil buah kemudian dirataratakan untuk mendapatkan nilai diamaternya, sedangkan berat buah diukur dengan timbangan digital. Untuk pengukuran karakteristik benih, sampel benih diambil dari setiap pohon induk dengan jumlah yang sama kemudian dikompositkan untuk setiap populasi. Sebanyak 150 benih diambil secara acak dan diukur panjang benih, lebar benih, tebal benih, panjang sayap, dan berat benihnya. Sebagian benih dari setiap populasi disimpan dalam ruang dry cold storage selama 4 bulan kemudian diuji perkecambahannya.

Tabel 1. Deskripsi geografis tegakan asal benih suren yang diuji dalam penelitian ini

\begin{tabular}{|c|c|c|c|c|c|c|}
\hline No & Lokasi & Letak geografis & $\begin{array}{l}\text { Tinggi } \\
\text { tempat } \\
\text { (m dpl) }\end{array}$ & $\begin{array}{l}\text { Curah } \\
\text { hujan } \\
\text { (mm/ } \\
\text { tahun) }\end{array}$ & $\begin{array}{l}\text { Rerata } \\
\text { suhu } \\
\left({ }^{\circ} \mathrm{C}\right)\end{array}$ & $\begin{array}{c}\text { Kelembaban } \\
(\%)\end{array}$ \\
\hline 1. & Cimalaka, Sumedang,Jawa Barat & $06^{\circ} 47^{\prime} \mathrm{LS}, 107^{\circ} 56^{\prime} \mathrm{BT}$ & 700 & 3.000 & 24 & 82 \\
\hline 2. & Wado, Sumedang, Jawa Barat & $07^{\circ} 00^{\prime} \mathrm{LS}, 108^{\circ} 06^{\prime} \mathrm{BT}$ & 500 & 2.200 & 26 & 70 \\
\hline 3. & Solok, Sumatera Barat & $01^{\circ} 20^{\prime} \mathrm{LS}, 100^{\circ} 25^{\prime} \mathrm{BT}$ & 895 & 3.300 & 24 & 82 \\
\hline 4. & Cugenang, Cianjur, Jawa Barat & $06^{\circ} 79^{\prime} \mathrm{LS}, 107^{\circ} 01^{\prime} \mathrm{BT}$ & 600 & 3.500 & 25 & 80 \\
\hline 5. & Gunung Raya, Kerinci, Jambi, & $02^{\circ} 26^{\prime} \mathrm{LS}, 101^{\circ} 40^{\prime} \mathrm{BT}$ & 900 & 3.645 & 19,6 & 84 \\
\hline 6. & Sanggaran Agung, Kerinci, Jambi & $02^{\circ} 11^{\prime} \mathrm{LS}, 101^{\circ} 52^{\prime} \mathrm{BT}$ & 830 & 3.645 & 23 & 85 \\
\hline 7. & Tanah Datar, Sumatera Barat & $00^{\circ} 55^{\prime} \mathrm{LS}, 100^{\circ} 35^{\prime} \mathrm{BT}$ & 650 & 3.000 & 24 & 83 \\
\hline
\end{tabular}

\section{Uji perkecambahan}

Pengujian perkecambahan dilakukan di Laboratorium Pengujian Benih, BPPTPTH Bogor. Uji perkecambahan benih dilakukan di germinator pada suhu $24-30^{\circ} \mathrm{C}$ dan kelembapan 90-95\%. Uji ini dilakukan pada benih sebelum disimpan dan benih yang sudah disimpan di DCS (drycold storage) pada suhu $4-8^{\circ} \mathrm{C}$ dan kelembapan nisbi 40 - 50\%. Sebanyak 100 butir benih dengan 4 ulangan ditabur pada media kertas merang dengan metode uji di atas kertas (Sudrajat, Megawati, \& Kartiana, 2007). Benih dinyatakan berkecambah bila telah muncul sepasang daun secara sempurna. Perkecambahan benih diamati setiap hari selama 14 hari.
Parameter yang diukur adalah daya berkecambah, kecepatan berkecambah dan ratarata waktu perkecambahan (Maguire, 1962).

\section{Analisis data}

Rancangan acak lengkap dengan faktor populasi asal benih digunakan untuk menguji perbedaan karakteristik morfo-fisiologi buah dan benih suren antar populasi. Data dianalisis dengan analisis ragam dan uji Duncan untuk menguji signifikasi perbedaan antara karakteristik buah dan benih dengan menggunakan perangkat lunak SPSS 21. Sebelumnya, data yang diperoleh diuji kenormalan datanya dan bila datanya tidak normal, data tersebut ditransformasi dengan 
arcsine $\sqrt{x}$ untuk meningkatkan kenormalan data (Zar, 1996). Korelasi sederhana (Pearson) digunakan untuk menemukan hubungan antar parameter benih dan bibit dengan faktor geoklimat (curah hujan, suhu rata-rata, ketinggian tempat, lintang dan bujur).

Keragaman fenotipe untuk setiap parameter dipisahkan ke dalam komponen-komponen yang disebabkan oleh faktor genetik dan non genetik (lingkungan) (Johnson, Robinson, \& Comstock, 1955). Keragaman fenotipe $(K F)$ adalah total keragaman antar fenotipe ketika ditumbuhkan pada suatu kisaran lingkungan, keragaman genetik $(K G)$ merupakan bagian dari keragaman fenotipe yang dapat dijadikan atribut untuk keragaman genetik antar populasi, sedangkan keragaman galat $(K L)$ merupakan bagian dari keragaman fenotipe yang disebabkan pengaruh lingkungan. Untuk membandingkan besarnya keragaman yang disebabkan oleh populasi dan lingkungan dan pengaruh bukan genetik lainnya, koefisien keragaman populasi $(K V G)$ dan keragaman lingkungan dan bukan genetik lainnya $(K V L)$ dihitung untuk parameter benih dan bibit dengan menggunakan keragaman populasi $(K G)$, keragaman lingkungan $(K L)$ dan rata-rata dengan rumus sebagai berikut:

$$
\begin{aligned}
K V G & =(K G)^{1 / 2} / \text { Mean, dan } \\
K V L & =(K L)^{1 / 2} / \text { Mean }
\end{aligned}
$$

Untuk menentukan besarnya keragaman populasi yang berkontribusi terhadap keragaman total, heritabilitas dalam arti luas $\left(H^{2}\right)$ dihitung sebagai berikut (Zheng et al., 2009):

$$
H^{2}=K G /(K G+K L)
$$

Kemajuan genetik (genetic gain, $G G$ ) sebagai persentase dari asumsi seleksi 5\% dari genetik superior (Intensitas seleksi $(I S)=2,06)$ dihitung dengan rumus:

$$
\begin{aligned}
& G A(\text { genetic advance })=I S . H^{2} . \sqrt{ } K F ; G G \\
& (\% \text { dari rata-rata })=(G A / X) \times 100,
\end{aligned}
$$

dimana $K F=$ keragaman fenotipe, $X=$ rata-rata parameter (Johnson et al., 1955).

Analisis komponen utama digunakan untuk menerangkan pola keragaman antar populasi. Analisis-analisis tersebut dilakukan dengan menggunakan perangkat lunak SPSS 21. Analisis komponen utama juga digunakan untuk mengidentifikasi parameter tanaman yang berkontribusi besar terhadap keragaman dan mengelompokan populasi yang mempunyai karakteristik morfofisiologi buah dan benih sama.

\section{HASIL DAN PEMBAHASAN}

\section{A. Hasil}

\section{Morfo-fisiologi buah dan benih}

Populasi asal benih berpengaruh sangat nyata terhadap semua parameter morfo-fisiologi benih suren yang diuji. Panjang buah berkisar antara 21,9mm (Solok) - 24,2mm (Wado) dan lebar buah berkisar 11,1 mm (Solok) dan 12,2mm (Cugenang). Jumlah benih isi dalam satu buah terbanyak dihasilkan oleh asal benih Sanggaran Agung (16,6 benih/buah), sedangkan rasio benih berisi dengan jumlah benih per buah tertinggi dihasilkan oleh asal benih Cimalaka $(0,64)$. Panjang benih berkisar antara 4,74mm (Solok) $5,70 \mathrm{~mm}$ (Cugenang), sedangkan lebar benih berkisar antara 3,23mm (Gunung Raya) $3,57 \mathrm{~mm}$ (Wado). Asal benih Gunung Raya memiliki sayap benih terpanjang $(11,27 \mathrm{~mm})$, sedangkan untuk lebar sayapnya, asal benih Cugenang memiliki sayap terlebar $(5,66 \mathrm{~mm})$. Asal benih Gunung Raya memiliki berat dan kadar air benih tertinggi dengan berat $0,833 \mathrm{~g}$ dan kadar air $12,1 \%$. Secara fisiologi yang dilihat dari daya berkecambahnya, asal benih dari populasi Cimalaka memberikan hasil terbaik dengan daya berkecambah $90,75 \%$ dan $51,75 \%$ untuk benih yang disimpan di DCS (suhu $4-8^{\circ} \mathrm{C}$, kelembapan nisbi 40 - 50\%) selama 4 bulan. Hal yang sama juga ditunjukkan oleh kecepatan berkecambahnya, masing-masing $9,30 \% \mathrm{etmal}^{-1}$ dan $5,90 \%$ etmal $^{-1}$ untuk benih yang disimpan selama 4 bulan (Tabel 2). 


\section{Korelasi antar parameter buah, benih dan faktor geoklimat}

Korelasi antar parameter morfo-fisiologi benih menunjukkan bahwa sebagian besar parameter tidak berkorelasi nyata dan hanya 8 pasang parameter yang saling berkorelasi. Panjang benih berkorelasi positif dengan jumlah benih isi $(r=0,77)$. Rasio benih isi terhadap jumlah benih total per buah berkorelasi negatif dengan jumlah benih hampa $(r=-0,84)$ dan dengan berat benih $(r=-0,80)$. Lebar sayap benih berkorelasi positif dengan tebal benih $(r=0,79)$ dan berat benih $(r=0,94)$. Daya berkecambah awal (sebelum simpan) berkorelasi positif dengan kecepatan berkecambah $(r=0,96)$, daya berkecambah dan kecepatan berkecambah setelah penyimpanan 4 bulan dengan koefisien korelasi sebesar masing-masing 0,82 dan 0,85. Begitu juga kecepatan berkecambah sebelum simpan berkorelasi positif dengan daya berkecambah setelah penyimpanan benih suren (Tabel 3). Faktor-faktor agroklimat seperti ketinggian tempat, curah hujan, suhu dan kelembaban udara secara umum tidak memberikan korelasi yang nyata terhadap parameter morfo-fisiologi benih, kecuali jumlah benih hampa yang berkorelasi negatif dengan suhu $(r=-0,788)$ dan lebar sayap benih yang berkorelasi negatif dengan ketinggian tempat lokasi asal benih $(r=-0,795)$.

Tabel 2. Morfo-fisiologi buah dan benih suren (rata-rata \pm SD) dari 7 populasi

\begin{tabular}{lllllllll}
\hline \multicolumn{1}{c}{ Population } & $\begin{array}{c}\mathrm{PF} \\
(\mathrm{mm})\end{array}$ & $\begin{array}{c}\mathrm{DF} \\
(\mathrm{mm})\end{array}$ & $\begin{array}{c}\text { JBI } \\
\text { (benih/ } \\
\text { buah) }\end{array}$ & $\begin{array}{c}\text { JBH (benih/ } \\
\text { buah) }\end{array}$ & RBI & $\begin{array}{c}\text { PB } \\
(\mathrm{mm})\end{array}$ & $\begin{array}{c}\text { LB } \\
(\mathrm{mm})\end{array}$ & $\begin{array}{c}\text { TB } \\
(\mathrm{mm})\end{array}$ \\
\hline Cimalaka & $23,9 \mathrm{c}$ & $12,1 \mathrm{ab}$ & $15,7 \mathrm{ab}$ & $9,0 \mathrm{~d}$ & $0,64 \mathrm{a}$ & $5,07 \mathrm{~cd}$ & $3,54 \mathrm{ab}$ & $0,69 \mathrm{bcd}$ \\
Wado & $24,2 \mathrm{~b}$ & $12,0 \mathrm{bc}$ & $15,3 \mathrm{~cd}$ & $9,4 \mathrm{~cd}$ & $0,61 \mathrm{~b}$ & $5,53 \mathrm{ab}$ & $3,57 \mathrm{a}$ & $0,77 \mathrm{bc}$ \\
Solok & $21,9 \mathrm{f}$ & $11,1 \mathrm{~d}$ & $14,0 \mathrm{e}$ & $10,1 \mathrm{c}$ & $0,57 \mathrm{~cd}$ & $4,74 \mathrm{e}$ & $3,22 \mathrm{c}$ & $0,67 \mathrm{cde}$ \\
Cugenang & $23,3 \mathrm{~d}$ & $12,2 \mathrm{a}$ & $15,8 \mathrm{ab}$ & $9,7 \mathrm{~cd}$ & $0,62 \mathrm{~b}$ & $5,70 \mathrm{a}$ & $3,33 \mathrm{bc}$ & $1,05 \mathrm{a}$ \\
Gunung Raya & $25,3 \mathrm{a}$ & $11,8 \mathrm{c}$ & $16,3 \mathrm{ab}$ & $11,5 \mathrm{~b}$ & $0,58 \mathrm{c}$ & $5,35 \mathrm{bc}$ & $3,23 \mathrm{c}$ & $0.52 \mathrm{e}$ \\
Sanggaran Agung & $23,7 \mathrm{c}$ & $11,9 \mathrm{c}$ & $16,6 \mathrm{a}$ & $12,8 \mathrm{a}$ & $0,56 \mathrm{de}$ & $4,90 \mathrm{de}$ & $3,46 \mathrm{ab}$ & $0,60 \mathrm{de}$ \\
Tanah Datar & $22,7 \mathrm{e}$ & $11,8 \mathrm{c}$ & $14,7 \mathrm{~d}$ & $11,7 \mathrm{~b}$ & $0,55 \mathrm{e}$ & $5,10 \mathrm{~cd}$ & $3,47 \mathrm{ab}$ & $0,84 \mathrm{~b}$ \\
\hline F-hit $(F$-test $)$ & $133,979^{* *}$ & $89,363^{* *}$ & $22,999^{* *}$ & $31,193^{* *}$ & $24,679 * *$ & $12,754^{* *}$ & $4,814^{* *}$ & $7,596^{* *}$ \\
\hline
\end{tabular}

Tabel 2. Lanjutan

\begin{tabular}{lllllllll}
\hline Populasi & $\begin{array}{l}\text { PSB } \\
(\mathrm{mm})\end{array}$ & $\begin{array}{l}\text { LSB } \\
(\mathrm{mm})\end{array}$ & $\begin{array}{l}\text { BB } \\
(\mathrm{gram})\end{array}$ & $\begin{array}{l}\text { KA } \\
(\%)\end{array}$ & $\begin{array}{l}\text { DB } \\
(\%)\end{array}$ & $\begin{array}{l}\text { KB } \\
(\% \text { etmal })\end{array}$ & $\begin{array}{l}\text { DBS } \\
(\%)\end{array}$ & $\begin{array}{l}\text { KCS } \\
(\% \text { etmal })\end{array}$ \\
\hline Cimalaka & $9,11 \mathrm{c}$ & $5,54 \mathrm{ab}$ & $0,560 \mathrm{c}$ & $10,9 \mathrm{bc}$ & $90,75 \mathrm{a}$ & $9,30 \mathrm{a}$ & $51,75 \mathrm{a}$ & $5,90 \mathrm{a}$ \\
Wado & $9,23 \mathrm{c}$ & $5,40 \mathrm{bc}$ & $0,756 \mathrm{~b}$ & $10,6 \mathrm{c}$ & $87,50 \mathrm{ab}$ & $8,95 \mathrm{a}$ & $39,00 \mathrm{~b}$ & $3,30 \mathrm{~b}$ \\
Solok & $8,30 \mathrm{~d}$ & $5,10 \mathrm{c}$ & $0,818 \mathrm{a}$ & $10,8 \mathrm{bc}$ & $\begin{array}{l}74,75 \mathrm{~d} \\
7,94 \mathrm{bc}\end{array}$ & $\begin{array}{l}25,25 \mathrm{~cd} \\
2,77 \mathrm{bc}\end{array}$ \\
Cugenang & $8,76 \mathrm{c}$ & $5,66 \mathrm{a}$ & $0,498 \mathrm{~d}$ & $11,4 \mathrm{~b}$ & $60,50 \mathrm{e}$ & $5,35 \mathrm{~d}$ & $15,25 \mathrm{~d}$ & $1,09 \mathrm{e}$ \\
Gunung Raya & $11,27 \mathrm{a}$ & $5,03 \mathrm{~d}$ & $0,833 \mathrm{a}$ & $12,1 \mathrm{a}$ & $83,00 \mathrm{bc}$ & $8,63 \mathrm{ab}$ & $32,75 \mathrm{bc}$ & $2,89 \mathrm{~b}$ \\
Sanggaran Agung & $10,22 \mathrm{~b}$ & $5,14 \mathrm{~cd}$ & $0,828 \mathrm{a}$ & $11,1 \mathrm{bc}$ & $77,00 \mathrm{~cd}$ & $7,94 \mathrm{bc}$ & $40,00 \mathrm{~b}$ & $1,79 \mathrm{~d}$ \\
Tanah Datar & $10,31 \mathrm{~b}$ & $5,27 \mathrm{~cd}$ & $0,774 \mathrm{~b}$ & $10,7 \mathrm{bc}$ & $70,75 \mathrm{~d}$ & $7,51 \mathrm{c}$ & $36,75 \mathrm{bc}$ & $2,24 \mathrm{~cd}$ \\
\hline F-hit $(F-t e s t)$ & $49,612^{* * *}$ & $7,084^{* *}$ & $84,386^{* *}$ & $6,094^{* *}$ & $50,681^{* *}$ & $63,433^{* *}$ & $9,113^{* *}$ & $57,889^{* *}$ \\
\hline
\end{tabular}

Keterangan: Angka yang diikuti oleh huruf yang sama dalam kolom yang sama menunjukkan perlakuan yang tidak berbeda nyata; $* *=$ berpengaruh nyata pada tingkat kepercayaan $99 \% ; \mathrm{PF}=$ panjang buah, $\mathrm{DF}=$ diameter buah, $\mathrm{JBI}=$ jumlah benih isi, $\mathrm{JBH}=$ jumlah benih hampa, $\mathrm{RBI}=$ rasio benih isi terhadap jumlah benih dalam buah, $\mathrm{PB}=$ panjang benih, $\mathrm{LB}=$ lebar benih, $\mathrm{TB}=$ tebal benih, PSB = panjang sayap benih, $\mathrm{LSB}=$ lebar sayap, $\mathrm{BB}=$ berat benih, $\mathrm{KA}=$ kadar air, $\mathrm{DB}=$ daya berkecambah, $\mathrm{KB}=$ kecepatan berkecambah, $\mathrm{RWB}=$ rata-rata waktu berkecambah, $\mathrm{DBS}$ = daya berkecambah setelah penyimpanan 4 bulan, $\mathrm{KCS}$ = kecepatan berkecambah setelah penyimpanan 4 bulan 
Tabel 3. Korelasi antar parameter morfo-fisiologi buah dan benih suren

\begin{tabular}{|c|c|c|c|c|c|c|c|c|c|c|c|c|c|c|c|}
\hline & $\mathrm{PF}$ & DF & JBI & JBH & RBI & PB & LB & $\mathrm{TB}$ & PSB & LSB & $\mathrm{BB}$ & $\mathrm{KA}$ & $\mathrm{DB}$ & $\mathrm{KC}$ & DBS \\
\hline$\overline{\mathrm{DF}}$ & 0,55 & & & & & & & & & & & & & & \\
\hline JBI & $0,77^{*}$ & 0,66 & & & & & & & & & & & & & \\
\hline JBH & 0,07 & $-0,16$ & 0,34 & & & & & & & & & & & & \\
\hline RBI & 0,31 & 0,57 & 0,19 & $-0,84^{*}$ & & & & & & & & & & & \\
\hline PB & 0,49 & 0,69 & 0,33 & $-0,35$ & 0,51 & & & & & & & & & & \\
\hline LB & 0,13 & 0,57 & 0,15 & $-0,18$ & 0,31 & 0,11 & & & & & & & & & \\
\hline TB & $-0,39$ & 0,40 & $-0,24$ & $-0,40$ & 0,31 & 0,56 & 0,16 & & & & & & & & \\
\hline PSB & 0,64 & 0,18 & 0,55 & 0,71 & $-0,45$ & 0,05 & $-0,04$ & $-0,49$ & & & & & & & \\
\hline LSB & $-0,05$ & 0,70 & 0,05 & $-0,67$ & 0,68 & 0,58 & 0,46 & $0,79^{*}$ & $-0,52$ & & & & & & \\
\hline BB & 0,03 & $-0,63$ & $-0,11$ & 0,65 & $-0,80^{*}$ & $-0,50$ & $-0,23$ & $-0,70$ & 0,49 & $0,94^{* *}$ & & & & & \\
\hline KA & 0,62 & 0,15 & 0,60 & 0,28 & 0,01 & 0,31 & $-0,62$ & $-0,27$ & 0,55 & $-0,25$ & 0,02 & & & & \\
\hline DB & 0,51 & 0,04 & 0,15 & $-0,22$ & 0,30 & $-0,18$ & 0,42 & $-0,66$ & 0,18 & $-0,17$ & 0,22 & $-0,11$ & & & \\
\hline $\mathrm{KB}$ & 0,39 & $-0,15$ & 0,02 & $-0,08$ & 0,07 & $-0,36$ & 0,35 & $-0,65$ & 0,24 & $-0,36$ & 0,41 & $-0,16$ & $\mathbf{0 , 9 6} \mathbf{6}^{\text {** }}$ & & \\
\hline DBS & 0,32 & 0,21 & 0,21 & 0,02 & 0,13 & $-0,34$ & 0,69 & $-0,51$ & 0,27 & $-0,05$ & 0,13 & $-0,31$ & $0,82^{*}$ & $\mathbf{0 , 8 3 ^ { * }}$ & \\
\hline KBS & 0,31 & 0,07 & $-0,07$ & $-0,54$ & 0,54 & $-0,23$ & 0,48 & $-0,43$ & $-0,17$ & 0,18 & $-0,20$ & $-0,44$ & $\mathbf{0 , 8 5}$ & 0,80 & 0,76 \\
\hline
\end{tabular}

Keterangan: lihat Tabel 2 untuk keterangan parameter morfo-fisiologi buah dan benih; * = nyata pada tingkat kepercayaan $95 \%, * *$ = nyata pada tingkat kepercayaan $99 \%$.

Tabel 4. Korelasi antar faktor geoklimat dengan parameter morfo-fisiologi buah dan benih suren

\begin{tabular}{ccccc}
\hline Parameter (Parameters) & KT & CH & SH & KLB \\
\hline PF & $-0,063$ & 0,017 & $-0,125$ & $-0,068$ \\
DF & $-0,652$ & $-0,145$ & 0,285 & $-0,233$ \\
JBI & 0,029 & 0,397 & $-0,342$ & 0,236 \\
JBH & 0,545 & 0,545 & $-\mathbf{0 , 7 8 8 ^ { * }}$ & 0,609 \\
RBI & $-0,549$ & $-0,317$ & 0,509 & $-0,441$ \\
PB & $-0,686$ & $-0,234$ & 0,594 & $-0,518$ \\
LB & $-0,683$ & $-0,681$ & 0,410 & $-0,482$ \\
TB & $-0,704$ & $-0,214$ & 0,658 & $-0,370$ \\
PSB & 0,339 & 0,302 & $-0,582$ & 0,426 \\
LSB & $-\mathbf{0 , 7 9 5}$ & $-0,336$ & 0,648 & $-0,436$ \\
BB & 0,560 & 0,064 & $-0,426$ & 0,178 \\
KA & 0,453 & 0,702 & $-0,504$ & 0,489 \\
DB & 0,015 & $-0,452$ & $-0,034$ & $-0,236$ \\
KB & 0,163 & $-0,415$ & $-0,151$ & $-0,130$ \\
DBS & $-0,037$ & $-0,376$ & $-0,186$ & $-0,008$ \\
KBS & $-0,055$ & $-0,450$ & 0,023 & $-0,127$ \\
\hline
\end{tabular}

Keterangan: lihat Tabel 2 untuk keterangan parameter morfo-fisiologi buah dan benih, KT = ketinggian tempat, $\mathrm{CH}=$ curah hujan tahunan, $\mathrm{SH}=$ suhu, $\mathrm{KLB}=$ kelembaban relatif, * = berbeda nyata pada tingkat kepercayaan $95 \%$.

3. Keragaman genetik, koefisien keragaman dan heritabilitas

Keragaman genetik beragam dari nilai tertinggi 274,574 (daya berkecambah) hingga nilai terendah 0,002 (rasio benih isi terhadap jumlah total benih per buah). Koefisien keragaman fenotipe $(K K F)$ dan koefisien keragaman genetik $(K K G)$ memberikan nilai tertinggi pada parameter kecepatan berkecambah setelah penyimpanan 4 bulan (masing-masing 
53,838 dan 53,370), sedangkan koefisien keragaman lingkungan (KKL) tertinggi dihasilkan oleh daya berkecambah benih setelah penyimpanan 4 bulan $(11,207)$. Nilai $K K F$ dan $K K G$ terendah ditunjukkan oleh lebar sayap benih (masing-masing 4,699 and 4,355) dan nilai terendah untuk $K K L$ adalah diameter buah $(0,665)$ (Tabel 5).

Keragaman genetik dan koefisien keragaman genetik untuk semua parameter buah dan benih suren ditemukan lebih tinggi daripada koefisien keragaman lingkungan. Besaran keragaman galat relatif lebih rendah daripada keragaman genetik untuk semua parameter, sedangkan koefisien keragaman fenotipe dan genetik sangat dekat satu dengan yang lainnya untuk semua parameter. Begitu pula dengan dugaan heritabilitas dalam arti luas yang berada pada kisaran 0,79 (lebar benih) sampai 0,99 (panjang buah, diameter buah dan lebar benih).

Tabel 5. Keragaman, koefisien keragaman populasi dan lingkungan, heritabilitas buah dan benih suren

\begin{tabular}{crrrrrrrr}
\hline Parameter & \multicolumn{1}{c}{ KF } & \multicolumn{1}{c}{ KG } & \multicolumn{1}{c}{ KL } & \multicolumn{1}{c}{ KKG } & \multicolumn{1}{c}{ KKF } & \multicolumn{1}{c}{ KKL } & H $^{2}$ & GG (\%) \\
\hline PF & 4,638 & 4,603 & 0,035 & 9,049 & 9,083 & 0,785 & 0,99 & 19 \\
DF & 0,547 & 0,541 & 0,006 & 6,254 & 6,289 & 0,665 & 0,99 & 13 \\
JBI & 2,475 & 2,368 & 0,108 & 10,104 & 10,331 & 2,154 & 0,96 & 20 \\
JBH & 4,084 & 3,953 & 0,131 & 19,494 & 19,814 & 3,548 & 0,97 & 40 \\
RBI & 0,002 & 0,002 & 0,000 & 7,309 & 7,462 & 1,502 & 0,96 & 15 \\
PB & 0,131 & 0,121 & 0,010 & 6,746 & 7,027 & 1,968 & 0,92 & 13 \\
LB & 0,029 & 0,023 & 0,006 & 4,455 & 5,005 & 2,281 & 0,79 & 8 \\
TB & 0,026 & 0,022 & 0,003 & 21,722 & 23,311 & 8,458 & 0,87 & 42 \\
PSB & 1,455 & 1,426 & 0,029 & 12,373 & 12,499 & 1,775 & 0,98 & 25 \\
LSB & 0,061 & 0,053 & 0,009 & 4,355 & 4,699 & 1,766 & 0,86 & 8 \\
BB & 0,019 & 0,019 & 0,000 & 18,078 & 18,187 & 1,980 & 0,99 & 37 \\
KA & 0,285 & 0,238 & 0,047 & 4,399 & 4,812 & 1,949 & 0,84 & 8 \\
DB & 280,101 & 274,574 & 5,527 & 22,126 & 22,348 & 3,139 & 0,98 & 45 \\
KB & 4,005 & 3,941 & 0,063 & 25,918 & 26,125 & 3,280 & 0,98 & 53 \\
DBS & 135,372 & 120,518 & 14,854 & 31,922 & 33,832 & 11,207 & 0,89 & 62 \\
KBS & 2,354 & 2,314 & 0,041 & 53,370 & 53,838 & 7,076 & 0,98 & 109 \\
\hline
\end{tabular}

Keterangan: lihat Tabel 2 untuk keterangan parameter morfologi buah dan benih, $\mathrm{KF}=$ ragam fenotipe, $\mathrm{KG}=$ ragam genotipe, $\mathrm{KL}$ = ragam lingkungan, $\mathrm{KKG}=$ koefisien ragam genetik, koefisien ragam fenotif, koefisien ragam lingkungan, $\mathrm{H} 2$ = heritabilitas, $\mathrm{GA}=$ kemajuan genetik

Kemajuan genetik berkisar antara $8 \%$ dan 109\% dengan lebar benih, lebar sayap benih dan kadar air benih yang memberikan nilai terendah dan kecepatan berkecambah setelah penyimpanan yangmemberikan nilai tertinggi. Beberapa parameter seperti panjang buah dan berat benih mempunyai heritabilitas yang tinggi $(0,99)$, tetapi koefisien keragaman genetik dan kemajuan genetiknya relatif rendah.

Analisis komponen utama menghasilkan 4 komponen yang memiliki nilai eigen di atas 1 dengan nilai kumulatif varians $94,12 \%$. Komponen utama pertama dan kedua menghasilkan masing-masing 33,19\% dan 29,17\% keragaman dari jumlah parameter yang ada. Komponen pertama terdiri dari lebar sayap benih, berat benih, tebal benih, rasio benih isi, jumlah benih hampa, dan panjang benih. Komponen tersebut merupakan indentitas dari parameter-parameter morfologi benih. Komponen kedua terdiri dari daya dan kecepatan berkecambah baik sebelum maupun setelah penyimpanan yang merupakan indikator kemampuan fisiologi benih. Grafik biplot sebaran populasi berdasarkan komponen utama pertama dan kedua disajikan pada Gambar 1. 


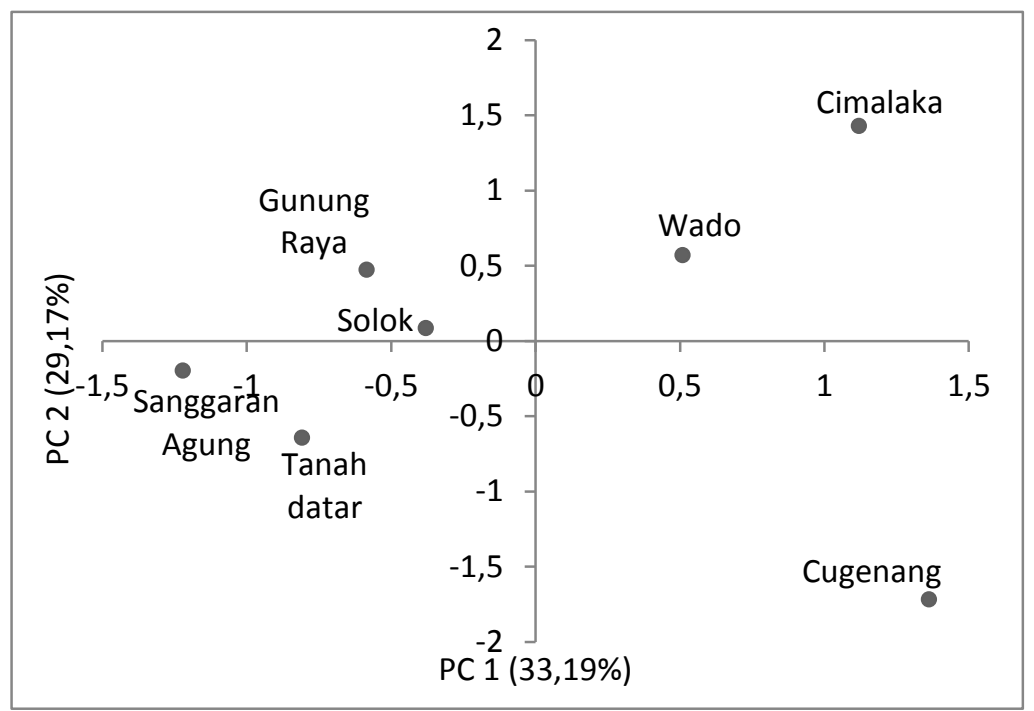

Gambar 1. Biplot pengelompokkan populasi suren berdasarkan morfo-fisiologi buah dan benih

\section{B. Pembahasan}

\section{Morfo-fisiologi benih dan bibit}

Perbedaan antar populasi yang nyata pada semua parameter yang diukur memberi indikasi adanya keragaman parameter benih dan bibit antar populasi atau asal benih. Keragaman ini menunjukkan adanya pengaruh lingkungan dan juga genetik serta interaksinya. Diduga, beberapa populasi suren telah menjadi ras lahan sebagai hasil dari proses adaptasi yang berlangsung beberapa generasi.

Populasi Cimalaka mempunyai karakteristik morfo-fisiologi benih dan bibit yang lebih baik dibandingkan populasi lainnya dengan 5 parameter terbaik, yaitu untuk rasio benih isi, daya berkecambah, kecepatan berkecambah, daya dan kecepatan berkecambah setelah penyimpanan 4 bulan. Populasi Cugenang mempunyai nilai karakteristik morfofisiologi benih dan bibit yang lebih rendah, terutama pada parameter fisiologi, yaitu daya dan kecepatan berkecambah benih. Keragaman morfo-fisiologi benih dari populasi berbeda telah diteliti juga pada beberapa jenis, seperti Picea aspera (Luo, Zhang, \& $\mathrm{Gu}, 2009$ ), Trigonobalanus doichangensis (Zheng et al., 2009), Pinus roxburghii (Ghildiyal et al., 2009), Pinus wallichiana (Rawat \& Bakshi, 2011), Senna siamea (Takuathung et al., 2012),
Calophyllum inophylum (Hathurusingha, Ashwath, \& Midmore, 2011), Cedrus deodara (Mughal \& Thapliyal, 2012), Faidherdia albida (Fredrick, Muthuri, Ngamau, \& Sinclair, 2015), dan Anthocephalus cadamba (Sudrajat, 2016). Keragaman fisiologi benih (khususnya perkecambahan) antar populasi juga diamati pada 7 populasi suren di China (Yousheng \& Sziklai, 1985) dan juga pada jenis lainnya seperti Pinus wallichiana (Rawat \& Bakshi, 2011), Faidherdia albida (Fredrick et al., 2015) and Pinus densata (Xu et al., 2016). Keragaman karakteristik buah dan benih dipengaruhi oleh perbedaan lokasi, pohon dalam suatu lokasi dan antar buah di dalam pohon tersebut yang dikontrol secara bersamaan oleh faktor genetik (pohon induk, keturunan) dan lingkungan, seperti iklim, tanah, posisi dalam tajuk dan kerapatannya (Pathak et al., 1984) yang mempengaruhi proses perkembangan benih.

Pengaruh lingkungan makin berkurang ketika benih ditumbuhkan pada kondisi yang sama, seperti di bak tabur di rumah kaca, namun untuk jenis suren pada penelitian ini, keragaman parameter perkecambahan benih antar populasi masih tinggi. Menurut Rawat dan Bakshi (2011), ketika benih ditumbuhkan pada kondisi yang sama, sering menghasilkan pola pertumbuhan yang berbeda yang dapat diinterpretasikan 
sebagai pengaruh genetik karena pengaruh lingkungan dianggap nol.

\section{Korelasi antar karakter buah, benih dan faktor geoklimat}

Panjang buah suren berkorelasi jumlah benih isi yang menunjukkan semakin panjang benih semakin banyak jumlah benih isi atau bernas. Menurut Pramono, Palupi, Siregar, dan Kusmana (2016), jumlah benih berisi per buah berkisar antara 1-34 benih dengan kapasitas optimum benih berisi sekitar 20 benih. Buah yang memiliki jumlah benih berisi lebih dari 20 menunjukkan kualitas yang lebih rendah. Pada penelitian ini jumlah benih berisi berkisar antara 0-36 benih, kisaran yang lebih lebar disebabkan karena populasi yang diuji lebih banyak dengan sebaran yang lebih luas. Jumlah benih isi berkorelasi negatif dengan jumlah benih hampa yang memberi indikasi makin banyak benih berisi dalam suatu buah makin sedikit benih hampanya dan berlaku sebaliknya. Hal ini ditunjukkan juga oleh rasio benih berisi yang berkorelasi negatif dengan jumlah benih hampa. Korelasi lainnya ditunjukkan oleh lebar sayap benih yang berkorelasi positif dengan tebal benih dan berat benih. Hasil ini sejalan dengan yang ditemukan oleh Sevik dan Topacoglu (2015) pada benih Pinus sylvestris yang melaporkan benih-benih yang lebih besar dan berat mempunyai lebar sayap yang lebih besar.

Parameter morfo-fisiologi benih secara umum tidak berkorelasi nyata dengan faktorfaktor geoklimat, kecuali untuk ketinggian tempat yang berkorelasi negatif dengan lebar sayap dan suhu yang berkorelasi negatif dengan jumlah benih berisi. Korelasi negatif antara ketinggian tempat dengan lebar sayap benih juga dilaporkan oleh (Wang et al., 2014) pada jenis Rhododendron pada berbagai ketinggian di Tibet. Morfologi benih berhubungan dengan penyebaran benih. Benih suren disebarkan oleh angin, tetapi kecepatan angin relatif rendah pada daerah dengan ketinggian tempat rendah sehingga benih-benih tersebut beradaptasi dengan mengembangkan ukuran sayapnya menjadi lebih lebar untuk mendukung benih dapat menyebar lebih jauh. Pada daerah-daerah yang lebih tinggi, angin bertiup lebih kencang sehingga benih beradaptasi pula dengan mengurangi ukuran sayapnya sehingga mengurangi kemampuan terbang benih (Wang et al., 2014). Korelasi negatif antara suhu dengan jumlah benih berisi berhubungan dengan penghambatan aktivitas fotosintesis pada kondisi suhu lebih rendah. Pada kondisi tersebut, kecenderungan alokasi reproduktif menurun dan kadang-kadang tanaman memitigasi upaya reproduktifnya dengan menghasilkan benihbenih dengan kualitas rendah (Alexander, van Kleunen, Ghezzi, \& Edwards, 2012). Suhu secara langsung berperan terhadap perkembangan benih, dimana peningkatan suhu pada batas optimal untuk perkembangan benih akan meningkatkan jumlah benih berisi dan laju produksi bahan kering pada benih (Kobata \& Uemuki, 2004).

\section{Keragaman, koefisien keragaman dan heritabilitas}

Pada penelitian ini, koefisien keragaman genetik untuk semua parameter morfo-fisiologi buah dan benih suren ditemukan lebih tinggi daripada koefisien keragaman lingkungan yang memberi indikasi bahwa komponen genetik berkontribusi sangat besar terhadap total keragaman untuk parameter-parameter tersebut. Beberapa penelitian sebelumnya juga menunjukkan bahwa sebagian besar parameter morfofisiologi buah dan benih jenis-jenis tanaman hutan dikendalikan sangat kuat oleh faktor genetik (Sudrajat, 2016). Faktor lingkungan, yang beragam antar lokasi dan populasi di dalam lokasi, hanya mempunyai pengaruh kecil.

Keragaman yang disebabkan oleh keragaman genetik memberi indikasi lingkup parameter yang dapat dipertimbangkan untuk seleksi. Pada penelitian ini, koefisien variasi genetik dan kemajuan genetik untuk parameter tebal benih, daya berkecambah, kecepatan berkecambah baik sebelum dan sesudah 
penyimpanan menunjukkan nilai yang tinggi. Koefisien keragaman genetik yang lebih tinggi menunjukkan bahwa pemuliaan untuk parameter-parameter tersebut dapat dicapai melalui seleksi sederhana, sedangkan nilai kemajuan genetik yang lebih tinggi menunjukkan bahwa rata-rata populasi untuk daya dan kecepatan berkecambah dapat bertambah melalui pemilihan genetik superior dengan intensitas 5\% (Rawat \& Bakshi, 2011). Umumnya benih-benih yang cepat berkecambah akan menghasilkan bibit yang lebih vigor dengan pertumbuhan yang lebih baik.

Pendugaan heritabilitas ini berguna sebagai indikator awal kemungkinan untuk seleksi satu atau lebih parameter. Nilai heritabilitas yang tinggi yang berpasangan dengan kemajuan genetik yang tinggi dihasilkan oleh parameter kecepatan berkecambah benih dengan heritabilitas 0,98 dan kemajuan genetik 53\% untuk kecepatan sebelum disimpan dan 109\% untuk kecepatan berkecambah setelah disimpan. Hal ini menunjukkan bahwa parameter-parameter tersebut mempunyai nilai genetik yang tinggi dengan jumlah komponen genetik aditif yang dapat diturunkan lebih tinggi. Nilai heritabilitas yang tinggi yang diikuti dengan kemajuan genetik yang tinggi cukup memadai dan akurat untuk pemilihan populasi terbaik, sedangkan nilai heritabilitas yang tinggi yang berpasangan dengan kemajuan genetik rendah seperti yang ditunjukkan panjang buah dan diameter buah, memberi indikasi bahwa parameter-parameter tersebut mempunyai lebih banyak komponen genetik non aditif daripada komponen aditifnya sehingga parameter tersebut tidak dapat digunakan sebagai kriteria seleksi yang baik (Gairola et al., 2011; Rawat \& Bakshi, 2011).

Biplot populasi suren berdasarkan analisis komponen utama terhadap parameter morfofisiologi benih dan bibit (Gambar 1) menghasilkan kecenderungan klasifikasi genetik 7 populasi suren dalam 3 kelompok. Kelompok I terdiri dari 4 populasi (Gunung Raya, Solok, Sanggaran Agung dan Tanah Datar), kelompok
II memiliki 2 anggota populasi (Cimalaka dan Wado), dan kelompok III hanya memiliki 1 populasi (Cugenang). Sebagian besar pengelompokan jarak populasi secara geografis ke dalam satu group menunjukkan bahwa populasi yang jaraknya berdekatan secara genetik memiliki kekerabatan yang lebih dekat. Kemungkinan aliran gen hanya terjadi pada daerah-daerah yang dekat saja atau juga benih untuk sistem budidaya di suatu tempat hanya berasal dari pohon-pohon yang ada di daerah terdekatnya.

\section{KESIMPULAN}

\section{A. Kesimpulan}

Nilai heritabilitas dalam arti luas pada semua parameter menunjukkan nilai yang tinggi. Parameter daya berkecambah dan kecepatan berkecambah memiliki nilai heritabilitas yang tinggi dan diikuti dengan nilai kemajuan genetik yang tinggi sehingga dapat dijadikan indikator penting untuk pemilihan populasi terbaik. Sebagian besar parameter benih dan bibit yang diamati tidak berkorelasi dengan faktor-fartor geoklimat. Komponen genetik berkontribusi sangat besar terhadap total keragaman untuk parameter morfo-fisiologi buah dan benih suren yang memberi indikasi adanya adaptasi yang berlangsung terus menerus yang menciptakan ras lahan. Pengelompokan populasi dengan menggunakan analisis komponen utama dalam hubungannya dengan jarak geografis menunjukkan bahwa sebagian besar populasi yang berdekatan secara geografis memiliki kedekatan genetik berdasarkan morfo-fisiologi buah dan benih.

\section{B. Saran}

Pengumpulan materi genetik untuk tujuan konservasi atau pemuliaan disarankan untuk dilakukan pada banyak populasi yang letaknya berjauhan karena ada dugaan populasi yang berdekatan (berada pada satu daerah seperti satu kabupaten) memiliki kedekatan secara genetik berdasarkan karakteristik morfo-fisiologi buah dan benih. Penggunaan penanda molekuler dapat 
dilakukan untuk mengklarifikasi dugaan tingkat keragaman genetik antar populasi suren.

\section{UCAPAN TERIMA KASIH}

Ucapan terima kasih disampaikan kepada Abay, Nurkim dan Endang Ismiati yang telah membantu pengukuran dan pengujian di lapangan dan di laboratorium pengujian benih Balai Penelitian Teknologi Perbenihan Tanaman Hutan Bogor.

\section{DAFTAR PUSTAKA}

Alexander, J. M., van Kleunen, M., Ghezzi, R., \& Edwards, P. J. (2012). Different genetic clines in response to temperature across the native and introduced ranges of a global plant invader. Journal of Ecology, 100(3), 771-781. http://doi.org/10.1111/j.13652745.2011.01951.x

Asmaliyah, \& Ismail, B. (2013). Potensi ekstrak daun rimau (Toona sp.) dalam menekan perkembangan serangan hama pada tanaman jabon (Anthocephalus cadamba) di lapangan. In Integrasi IPTEK dalam Kebijakan dan Pengelolaan Hutan Tanaman di Sumatera Bagian Selatan (pp. 169-178). Palembang: Balai Penelitian Kehutanan Palembang.

Chen, C.-M. (2012). Antioxidation activity and total phenolic contents of various Toona sinensis extracts. African Journal of Biotechnology, 11(73), 13831-13837. http://doi.org/10.5897/AJB12.2086

Darwiati, W. (2009). Uji efikasi ekstrak tanaman suren (Toona sinensis merr) sebagai insektisida nabati dalam pengendalian hama daun (Eurema spp. dan Spodoptera litura f.). Institute Petanian Bogor. Retrieved from http://repository.ipb.ac.id/bitstream/handle/12 $3456789 / 5838 / 2009$ wda.pdf? sequence $=4 \&$ is Allowed $=y$

Edmonds, J. M., \& Staniforth, M. (1998). Toona sinensis: Meliaceae. Curtis's Botanical Magazine, 15, 186-193. http://doi.org/10.1111/1467-8748.00169

Fredrick, C., Muthuri, C., Ngamau, K., \& Sinclair, F. (2015). Provenance variation in seed morphological characteristics, germination and early seedling growth of Faidherbia albida. Journal of Horticulture and Forestry, $7(5)$, 127-140. http://doi.org/10.5897/JHF2015.0392

Gairola, K. C., Sharma, A. R. N. G., \& Dwivedi, A. K. (2011). Variability in Seed Characteristics of Jatropha curcas Linn . From Hill Region of
Uttarakhand. Bulletin of Environment, Pharmacology \& Life Sciences, 1(1), 64-69.

Ghildiyal, S. K., Sharma, C. M., \& Gairola, S. (2009). Environmental variation in seed and seedling characteristics of Pinus roxburghii Sarg. From Uttarakhand, India. Applied Ecology and Environmental Research, 17(2), 121-129.

Hathurusingha, S., Ashwath, N., \& Midmore, D. (2011). Provenance variations in seed-related characters and oil content of Calophyllum inophyllum L. in northern Australia and Sri Lanka. New Forests, 41(1), 89-94. http://doi.org/10.1007/s11056-010-9212-1

Johnson, H. W., Robinson, H. F., \& Comstock, R. . (1955). Estimates of Genetic and Environmental Variability in Soybeans. Agronomy Journal, 47, 314-318. http://doi.org/10.2134/agronj1955.000219620 04700070009x

Kobata, T., \& Uemuki, N. (2004). High temperatures during the grain-filling periode do not reduce the potential grain dry matter increase of rice. Agronomy Journal., 96, 406-414.

Luo, J. X., Zhang, X. ., \& Gu, W. . (2009). Biogeographic differences in cone, needle and seed morphology among natural Picea asperata populations in Western China. Forestry Study in China, 7(2), 1-6.

Maguire, J. D. (1962). Speed of germination-aid selection and evaluation for seedling emergence and vigor. Crop Science, 2, 176177.

http://doi.org/10.2135/cropsci1962.0011183X $000200020033 x$

Mughal, A. H., \& Thapliyal, R. C. (2012). Provenance variation in cone and seed characteristics of Cedrus deodara (D. DON) G. DON in Jammu and Kashmir. Forestry Studies in China, 14(3), 193-199. http://doi.org/10.1007/s11632-012-0306-z

Pathak, P. S., Debroy, R., \& Rai, P. (1984). Autecology of (Lam) de Wit. seed polymorphism and germination. Tropical Ecology, 15, 1-10.

Pramono, A. A., Palupi, E. R., Siregar, I. Z., \& Kusmana, C. (2016). Characteristics of Surian Flower, Fruit and Seed Productions (Toona sinensis (A. Juss.) M. Roem.) in Sumedang, West Java. Tropical Life Sciences Research, 27(1), 77-91.

Rawat, K., \& Bakshi, M. (2011). Provenance variation in cone, seed and seedling characteristics in natural populations of Pinus wallichiana A.B. Jacks (Blue Pine) in India. Annals of Forest Research, 54(1), 39-55. 
Sevik, H., \& Topacoglu, O. (2015). Variation and inheritance pattern in cone and seed characteristics of scots pine (Pinus sylvestris L.) for evaluation of genetic diversity. Journal of Environmental Biologyment, 36(September), 1125-1130.

Sevik, H., Yahyaoglu, Z., \& Turna, I. (2012). Genetic diversity in plants. In Mahmut Çalişkan (Ed.), Genetics diversity in plants (pp. 231-248). Rijeka, Croatia: InTech. http://doi.org/10.5772/32884

Sudrajat, D. ., Megawati, \& Kartiana, E. R. (2007). Penentuan metode pengujian kadar air, berat 1000 butir, dan perkecambahan benih suren. Jurnal Penelitian Hutan Tanaman, 4(3), 151164.

Sudrajat, D. J. (2016). Genetic variation of fruit, seed, and seedling characteristics among 11 populations of white jabon in Indonesia. Forest Science and Technology, 12(1). http://doi.org/10.1080/21580103.2015.10078 96

Takuathung, C. N., Pipatwattanakul, D., \& Bhumibhamon, S. (2012). Provenance variation in seed morphometric traits and growth performance of Senna siamea (Lam.) erwin et barneby at lad krating plantation, Chachoengsao Province, Thailand. Kasetsart Journal - Natural Science, 46(3), 394-407.

Wang, Y., Wang, J., Lai, L., Jiang, L., Zhuang, P., Zhang, L., ... Baskin, C. C. (2014). Geographic variation in seed traits within and among forty-two species of Rhododendron (Ericaceae) on the Tibetan plateau: Relationships with altitude, habitat, plant height, and phylogeny. Ecology and Evolution, 4(10), 1913-1923. http://doi.org/10.1002/ece3.1067
Whitmore, T. C. (1998). Potential Impact of Climatic Change on Tropical Rain Forest Seedlings and Forest Regeneration. Climatic Change, 39, 429. http://doi.org/10.1023/A:1005356906898

Wu, J., Peng, W., Yi, J., Wu, Y., Chen, T., Wong, K., \& Wu, J. (2014). Chemical composition, antimicrobial activity against Staphylococcus aureus and a pro-apoptotic effect in SGC7901 of the essential oil from Toona sinensis (A. Juss.) Roem. leaves. Journal of Ethnopharmacology, 154(1), 198-205. http://doi.org/10.1016/j.jep.2014.04.002

Xu, Y., Cai, N., He, B., Zhang, R., Zhao, W., Mao, J., ... Woeste, K. (2016). Germination and early seedling growth of Pinus densata Mast. provenances. Journal of Forestry Research, $27(2)$, 283-294. http://doi.org/10.1007/s11676-015-0186-x

Yousheng, C., \& Sziklai, O. (1985). Preliminary study on the germination of Toona sinensis (A. Juss.) roem. seed from eleven Chinese provenances. Forest Ecology and Management, 10(3), 269-281. http://doi.org/10.1016/0378-1127(85)90119-7

Zar, J. H. (1996). Biostatistical Analysis (3rd ed.). Prentice Hall. Retrieved from https://books.google.co.id/books/about/Biosta tistical_Analysis.html?id=bNgPAQAAMAA J\&redir_esc $=y$

Zheng, Y. L., Sun, W. B., Zhou, Y., \& Coombs, D. (2009). Variation in seed and seedling traits among natural populations of Trigonobalanus doichangensis (A. Camus) Forman (Fagaceae), a rare and endangered plant in southwest China. New Forests, 37(3), 285294. http://doi.org/10.1007/s11056-008-9124- 